\title{
PROFESSIONAL AND ETHICAL STANDARDS FOR CIVIL SERVANTS OF INTERNATIONAL INTERGOVERNMENTAL ORGANIZATIONS
}

\section{Tetiana Syroid}

\section{INTRODUCTION}

The development of international relations has led to the creation of international intergovernmental organization (hereinafter - IGO), which, as noted by Prof. Franz Liszt, being called to a greater or lesser number of states to manage common interest, are legitimate international agencies by virtue of their international authority ${ }^{1}$. IGOs have an important place on the international scene and, together with states, act as subjects of international law. Modern IGO is a great, well-organized, effective system that promotes certain interests of the founding states. However, it should be noted that each system of government, public authority, or international organization is not just an abstract machine devoid of human subjective factor. Qualified and independent staff plays an essential role in its work. In view of this, international legal regulation of the status and activity of employees of international organizations is intended to ensure the proper level of their capacity, competence and independence ${ }^{2}$.

To address the goal the states deal with, team of skilled employees of the widest possible geographical representation whose activity meets the highest ideals of humanity is needed. Staff is the most important asset of any organization. The IGO staff is international civil servants by their status.

It should be mentioned that the creation of a system of international organizations as specialized bodies of international cooperation after the World War II, was carried out during the existence of some differences between the states. To ensure the high level of independence of the new system, it was necessary to separate sector-oriented activity from the political core of the organization. Thus, a coherent and unified international civil service was created, the activity of which was to be based on common standards, methods and mechanisms for staff that would avoid serious

1 Franz von Liszt. (1909). Mezhdunarodnoe pravo $v$ sistematicheskom izlozhenii [International law in systematic content]. (V.E. Grabar, Trans). Moscow: Tipografiia K. Mattissena [in Russian].

${ }^{2}$ Report of the International Civil Service Commission for the year 2017, A/72/30. (2017). undocs.org. Retrieved from https://undocs.org/en/A/72/30 [in English]. 
inconsistencies in terms of service and competition during recruitment and promote staff mobility within the system. International civil service has undergone significant changes during its development and establishment.

The international civil service is responsible for the implementation of the goals and objectives of the IGOs. It is based on the rich traditions of public administration that have evolved in the member states, traditions based on the principles of competence, integrity, impartiality, independence and prudence. International civil servants are called to serve the ideals of peace, which is the basis for the functioning of modern IGOs, respect for fundamental rights without any distinction, economic and social progress of all countries and of international cooperation. As employees of an IGO, they do not represent the unilateral interests of the state under the instructions they receive, but common interests according to a free personal confidence ${ }^{3}$. They act on behalf of the organization as a whole. IGO's staff promotes the rule of diplomacy in international relations.

Nowadays, the new challenges for states, in particular, terrorism, trafficking in human beings, illegal migration, etc., could not fail to reflect on modern IGOs that should respond in time and adequately to them, correct the directions, approach of their activity, where, undoubtedly, the main burden lies on their employees. In this regard, the international community should make efforts to proper selection and training of its officials and create appropriate conditions (develop, improve the legal framework for their functioning, improve standards of conduct in different circumstances, create an institutional basis for the protection of their personal rights and interests) to fulfill their responsibilities.

Based on the above, the topic of the article is relevant and caters to contemporary needs.

It is worth noting that some issues regarding the legal status of the IGO's staff were considered in scientific works of domestic and foreign scientists devoted to the law of international organizations, including: M. Baimuratov, V. Butkevych, K. Koliar, O. Kuchyk, P. Lukin, M. Mitrofanov, G. Morozov, T. Neshatayeva, V. Seytimova, T. Symonian, A. Fedotov, T. Tsygankov, A. Shulipa and others. The research of such authors as B.B. Butler, F.P. Walters, A. Evans, J. Langrod, D. Owen, J.P. Rennige, and F. Sayershted, became significant achievements in this field. At the same time, the chosen topic requires further research, taking into account the current realities of functioning of IGOs and their staff.

3 Franz von Liszt. (1909). Mezhdunarodnoe pravo $v$ sistematicheskom izlozhenii [International law in systematic content]. (V.E. Grabar, Trans). Moscow: Tipografiia K. Mattissena [in Russian]. 
The purpose of the article is to analyze the provisions of universal and regional acts of IGOs (the UN, WIPO, OSCE, Council of Europe, CIS) containing standards of professional and ethical conduct for civil servants; to define the role of standards in the creation of cohesive management culture of an IGO and their impact on the external activity of organization and adherence to generally accepted principles of international law which is the basis of global stability, protection of values and progressive development; to make relevant conclusions and recommendations.

\section{International universal professional and ethical standards for civil servants of IGOs}

The successful functioning of any IGO requires favorable conditions for staffing. This requires systems, rules and procedures that set a common standard of behavior and activity and ensure that each employee's work contributes to the achievement of common goals and objectives. With respect to the United Nations (hereinafter - the UN), the following objectives have a global character: the maintenance of international peace and security, the development of cooperation between Member States in all spheres, and the promotion and development of respect for human rights and freedoms (p. 165) ${ }^{4}$. The purpose of the Organization is to deprive future generations of the disasters of war and to provide every man, woman and child with the opportunity to live with dignity in freedom. Such highest ideals have not lost their relevance nowadays.

The status of the UN staff is governed by a number of constituent and internal legal acts of the Organization. The UN Charter grants its officials the status of international civil servants, which in turn confers on them the relevant rights and responsibilities (Art. $100 \mathrm{UN}$ Charter) ${ }^{5}$. The behavior of such servants must be in accordance with high ethical standards. For this purpose, international civil servants must be guided by the unique Standards of Conduct for International Civil Service (hereinafter - SCICS), which were originally developed in 1954 by the International Civil Service Advisory Board. The principles and norms enshrined in the document, which came to light in 1954, have stood the test of time and become part of the culture and heritage of international organizations. Of the International Civil Service Commission (hereinafter - ICSC) twice reviewed the SCICS - in 2001 and in 2013. During the development of the latest version of the Standard that was

4 Syroid, T.L. (2017) Vnutrishnia systema vreghuliuvannia sporiv Orghanizatsiyi Obiednanykh Natsiy [Internal Dispute Settlement System of the United Nations]. V.N. Karazin Kharkiv National University Journal, 23, 165-168 [in Ukrainian].

${ }^{5}$ Charter of the United Nations. (n.d.). www.un.org. Retrieved from https://www.un.org/ en/charter-united-nations/index.html [in English]. 
approved by the UN General Assembly A/RES/67/257, ICSC stemmed from the fact that the internal culture of every international organization has its own characteristics, but they face similar ethical problems.

The SCICS is intended to become guidelines for the ethical conduct of employees of international organizations. Not only do they inform, but also inspire officials of international organizations to uphold the highest ethical and moral values. They reflect the philosophical concept behind the international civil service. Standards are a comprehensive codification of rules designed to regulate the various fields of activity of international civil servants, in particular, they establish the guidelines of the international civil service, define the rules governing the official relationship of international civil servants, abuse of office, conflict of interests, disclosure of information, use of the UN resources, role of the secretariats, sets restrictions after the end of international civil service, contains rules on relations between staff and administration, Member States and governing bodies, public relations, the media, the principle of respect for different customs and cultures, rules on safety and security, personal conduct of international civil servants, nonorganizational work and off-duty activity, gifts and awards from sources outside the organization ${ }^{6}$.

The UN Staff Regulations and Rules stipulate that employees should share and adhere to the principles set out in the UN Charter, including the belief in fundamental human rights, dignity and value of the human being and the equality of men and women. Employees should show respect for all cultures; they should not discriminate against any person or group of persons or in any other way abuse the power and powers conferred on them. Employees must ensure a high level of performance, competence, integrity and loyalty. The notion of good faith includes but is not limited to honesty, impartiality, fairness, honesty and truthfulness in all matters pertaining to their work and status (regulation 1.2) ${ }^{7}$. The concept of good faith, with fortified the UN Charter covers all aspects of behavior of an international civil servant and includes such qualities as honesty, truthfulness, impartiality and incorruptibility. These qualities are no less important than the competence and capacity, which are also enshrined in the Charter. Tolerance and understanding are basic human values. They are also fundamental values for international civil servants, who must equally respect everyone without

\footnotetext{
${ }^{6}$ Shulipa O. (2015). Standarty povedinky mizhnarodnyh tsyvilnyh sluzhbovtsiv [Standards of Conduct for the International Civil Servants]. Scientific Journal "Chronicles of KUL», 2, 368-371 [in Ukrainian].

7 Staff Rules and Staff Regulations of the United Nations, ST/SGB/2014/1. (2014). undocs.org. Retrieved from https://undocs.org/en/ST/SGB/2014/1 [in English].
} 
distinction on whatever grounds. Such respect contributes to the creation of such a climate and conditions that meet the common needs (para. 5,6$)^{8}$.

In addition, in order to maintain the impartiality of the international civil service, international civil servants should remain independent of any authority outside the organization. In accordance with their oath of office, they must not solicit or accept instructions from any government, person or other party outside the organization. It should also be emphasized that international civil servants do not represent their national governments or other parties or the leaders of their policies. This rule applies equally to international civil servants who have been seconded by governments and those sent by other parties. International civil servants must always remember that, by adopting the Statute and the relevant legal documents of each organization, Member States and their representatives have undertaken to respect their independent status. Impartiality should be understood as tolerance and restraint, especially with regard to political and religious beliefs. The personal opinions of international civil servants remain intact, however, unlike an individual, they are not allowed to stand or express their views on controversial issues, whether in their personal capacity or as members of a group. This does not mean that international civil servants should abandon their personal political views or national outlook. This, however, means that they must constantly reflect a broad international outlook and a spirit of understanding about the international community as a whole. International civil servants responsible for implementing projects in specific countries or regions may be invited to exercise special caution while maintaining their independence. From time to time they may receive instructions from the receiving State, but such instructions shall not jeopardize their independence. If, at any time, they believe that such instructions threaten their independence, they should consult their managers.

In addition, international civil servants should refrain from providing assistance to third parties in their relations with the organization in cases where this may lead to actual or perceived preferential treatment. This is particularly important in procurement matters or in the negotiation of possible engagement. Occasionally, international civil servants, by virtue of their position or their functions, may, in accordance with the organization's policy, be required to provide information about certain personal assets in order for the organization to be satisfied that there is no conflict of interest. In doing so, organizations must maintain the confidentiality of all such disclosed information and use it only for a specific purpose or in the manner permitted

${ }^{8}$ Standards of Conduct for the International Civil Service. (n.d.). unesdoc.unesco.org. Retrieved from https://unesdoc.unesco.org/ark:/48223/pf0000230879 [in English]. 
by relevant international civil employees. International civil servants should also advise in advance of a possible conflict of interest arising in the course of their duties and consult on mitigation and settlement. They must carry out their duties and conduct their personal affairs so that the public's confidence in their honesty and the integrity of their organization is maintained and strengthened (para. 8-10, 12, 24) .

In case of actual or potential conflict of interests, when as a result of the act or omission, the personal interests of the employee conflict with the performance of his or her official duties and functions or with the requirements of honesty, independence and impartiality shown to the employee as to international civil servant, employee must report such conflict to the head of their unit (regulation $1.2(\mathrm{~m}))^{10}$. Conflicts of interest include circumstances in which international civil employees, directly or indirectly, may not profit properly or allow a third party to benefit improperly through their links with the organization. Conflicts of interest may arise as a result of personal or family business relationships of an employee of an international organization with third parties, individuals, beneficiaries or other parties. Risk factors associated with conflicts of interest can usually arise at two levels: in the form of organizational conflict of interest and in the form of a conflict of personal interests. Organizational conflict of interest arises when, because of other activities or relationships, the organization cannot impartially provide services, the objectivity of the organization when conducting its work is exposed or may be jeopardized, or the organization receives an undeserved competitive advantage. Conflict of personal interests can generally be understood as a situation in which a person's interest conflicts or may conflict with the performance of official duties. In the event of a conflict of interest or the possibility of its occurrence, information about it should be made public, it should be given due attention and it should be regulated in the highest interests of the organization. Issues of conflict of interest can be very sensitive and therefore require careful consideration (para. 23) ${ }^{11}$.

Attention should also be drawn to the fact that all P-1 and above staff are required to submit declarations of income and financial assets at the appointment and with the frequency established by the Secretary-General of

9 Standards of Conduct for the International Civil Service. (n.d.). unesdoc.unesco.org. Retrieved from https://unesdoc.unesco.org/ark:/48223/pf0000230879 [in English].

10 Staff Rules and Staff Regulations of the United Nations, ST/SGB/2014/1. (2014). undocs.org. Retrieved from https://undocs.org/en/ST/SGB/2014/1 [in English].

${ }^{11}$ Resolution adopted by the General Assembly Statute of the United Nations System Staff College in Turin, Italy, A/RES/55/278. (n.d.). documents-dds-ny.un.org. Retrieved from https://documents-dds-ny.un.org/doc/UNDOC/GEN/N00/575/77/PDF/N0057577.pdf?OpenElement [in English]. 
the UN for themselves, their husbands/wives and their children on their content. The income and financial assets declaration shall include information showing that the possession of assets and the economic activities of employees, their spouses and dependent children does not conflict with their official responsibilities or the interests of the UN (regulation $1.2(\mathrm{n}))^{12}$.

An essential guarantee of ensuring the impartiality and independence of the IGO in its relations with other international organizations and states is the provision in its internal regulations of the restriction on the acceptance by employees of honorary titles, awards, services, gifts or monetary remuneration in connection with the performance of official duties. This situation may result in a real or potential conflict of interest and make the organization a debtor to the giver.

Thus, usually small gifts from non-governmental sources that are acceptable in society or as a tribute to tradition are acceptable but should be reported to the head of department or unit. Even when given permission, employees should try not to give the impression that personal gain may not properly affect professional decisions. However, in order to prevent the unfavorable impression of an international civil service, international civil servants should not, without the permission of the administrative manager, accept any honorary titles, awards, gifts, services or material benefits of more than symbolic value, of which there were sources outside the organization. International civil servants should not receive additional payments and other subsidies from governments or from any other sources before, during or after their work in the UN system, if such payments are related to this work $(\text { para. } 50,51)^{13}$.

The Standards also contains provisions that set out the specificities of communication between staff members and the media. Thus, for the effective functioning of the UN the Organization must have public support. In this regard, it is the responsibility of all international civil servants to promote a better understanding of the goals and activity of their organization. This requires that international civil servants are aware of the achievements of their organizations and familiar with the work of the UN system as a whole. International civil servants also do not have to make public their personal complaints or publicly criticize their organizations. International civil servants should always strive to maintain good reputation of the international civil

12 Staff Rules and Staff Regulations of the United Nations, ST/SGB/2014/1. (2014). undocs.org. Retrieved from https://undocs.org/en/ST/SGB/2014/1 [in English].

${ }^{13}$ Resolution adopted by the General Assembly Statute of the United Nations System Staff College in Turin, Italy, A/RES/55/278. (n.d.). documents-dds-ny.un.org. Retrieved from https://documents-dds-ny.un.org/doc/UNDOC/GEN/N00/575/77/PDF/N0057577.pdf?OpenElement [in English]. 
service in accordance with their pledge of loyalty. When communicating with the media, the principle of openness and transparency of information must be respected, this is an effective means of disseminating information about the tasks of organizations. Organizations should provide appropriate guidelines and procedures that should be based on the following principles: international civil servants should proceed on behalf of their organization and should therefore refrain from presenting personal feedback and opinions; under no circumstances should they use the media in their own interest, make public complaints, disclose non-disclosable information, or seek to influence policy decisions made by their organizations (para. 35-38) ${ }^{14}$.

Employees may also be subject to certain restrictions, both during and after the service. Thus, upon completion of UN system work, international civil servants should not improperly use their previous position, including through the unauthorized use or dissemination of classified or confidential information; international civil servants, including those working in procurement services and as procurement staff, should not seek to unduly influence the organization's decisions in the interests or requests of third parties in order to obtain employment with such third parties (para. 26). Employees involved in the procurement process are prohibited from engaging in certain activities after they have stopped working at the UN. We are talking about employees who are dismissed, terminated or retired. The list of activities that constitute "participation in the procurement process" is contained in the bulletin of the Secretary-General ST/SGB/2006/15. These include, in particular, the selection of potential contractors and suppliers, participation in the contracting process. Former employees who have participated in the procurement process at the UN are not allowed to take up employment or accept job offers from any UN contractor or supplier within one year of termination of service. In addition, former employees who participated in the procurement process were banned from using the UN administrative resource for two years ${ }^{15}$.

It is important to emphasize that the United Nations System Staff College (hereinafter - the UNSSC) was established to provide training and continuous training for UN system staff, in particular in the areas of socio-economic development, peace and security and internal governance. The UNSSC is an independent, system-wide institution dedicated to the accumulation and

${ }^{14}$ Resolution adopted by the General Assembly Statute of the United Nations System Staff College in Turin, Italy, A/RES/55/278. (n.d.). documents-dds-ny.un.org. Retrieved from https://documents-dds-ny.un.org/doc/UNDOC/GEN/N00/575/77/PDF/N0057577.pdf?OpenElement [in English].

15 Secretary-General's bulletin Post-employment restrictions, ST/SGB/2006/15. (2006). undocs.org. Retrieved from https://undocs.org/en/ST/SGB/2006/15 [in English]. 
dissemination of knowledge and training to foster coherent governance across the UN system. It provides for the development of strategic civil leadership and management skills for international civil servants to enhance system-wide collaboration in areas within the overall competence of different organizations; increase of efficiency of activity; strengthen cooperation with Member States and specialized agencies, regional commissions, nongovernmental organizations and civil society in order to create more coherent system-wide governance. The UNSSC operates in light of the needs expressed by the institutions of the UN system and in close cooperation with vocational training institutes (Art. 1, 2) ${ }^{16}$.

Employees should also possess the necessary level of professional skills. Annex II to the ICSC Report A/57/30 "Basic Professional Qualification for Senior Leadership" identifies qualities such as the ability to manage the transformation process; ability to maximize the potential of employees; ability to be driven by results; ability to establish partnerships; communicative; prudence and decision-making skills and more.

Thus, the ability to manage the transformation process is a professional quality that encompasses the ability to evaluate prospects and develop strategy in broad context of the organization's objectives and global contexts, including program goals, priorities, values and other factors. This ability also includes the ability to create a work environment that encourages creativity, a sense of commitment and perseverance, even in adverse circumstances, persuading others to adopt an innovative approach.

The ability to maximize the potential of employees is to be able to inspire, engage, and direct others to achieve goals of shared mission. Such professional quality also includes the ability to set an example for imitation, to foster mutual trust and commitment; create favorable conditions; cooperate with employees on setting realistic expectations in work; respond to what is happening and expect the appropriate response from others; provide mentoring as needed; establish and maintain working relationships characterized by a spirit of cooperation; create a culture that encourages high standards, a spirit of collectivism and a sense of pride.

The ability to be results-oriented should be understood as the willingness to be responsible for the results. A person who is required to possess such professional quality should be able to identify opportunities to improve systems and improve performance; take into account the wishes of customers, as well as the interests of

\footnotetext{
${ }^{16}$ Resolution adopted by the General Assembly Statute of the United Nations System Staff College in Turin, Italy, A/RES/55/278. (n.d.). documents-dds-ny.un.org. Retrieved from https://documents-dds-ny.un.org/doc/UNDOC/GEN/N00/575/77/PDF/N0057577.pdf?OpenElement [in English].
} 
parties and Member States; manage resources under conditions of changing priorities in order to achieve the expected results on time and within budget and quality standards, adjust plans and priorities if circumstances change.

Another core professional skill is the ability to forge partnerships, which includes the ability to forge relationships and strengthen alliances; encourage and support cross-functional and collaborative activities; take into account the broad priorities of the organization and different perspectives; collaborate and find common ground with a wide range of stakeholders; identify and use opportunities to improve work through partnerships. Employee endowed with such a quality must strive for consensus and establish relationships that contribute to the achievement of goals; approach the solution of the problem in order to provide conditions favorable to all; promote, through persuasion and negotiation with the parties, both inside and outside the organization, the achievement of the organization's goals. In addition, communication is an important component of employee professionalism. Such a skill requires the person to be able to explain, propagate and express opinions in a convincing manner; to be an effective advocate of the values of the organization and its tasks; be a careful listener; be attentive to and respond to the problems, needs, and feelings of others; negotiate with individuals and groups, both within and outside the organization; be tactful, listen to the opinions of others; treat people with respect; encourage open exchange of views ${ }^{17}$.

Staff Regulations and Rules of the International Bureau of the World Intellectual Property Organization (hereinafter - the WIPO) provides for the acceptance and signature by the staff of the organizations, prior to the beginning of their official duties, oaths or statements of the following content: "I solemnly swear (alternatively: I confirm, declare, I promise) to perform, with all loyalty and prudence, the functions fully entrusted to me as an employee of the International Bureau, to perform these functions and behave with the sole interests of the International Bureau, in accordance with the Rules of Conduct for International Civil Servants, and do not seek or accept instructions or assistance in the performance of my duties by any government or other body outside the International Bureau". The oath is given (or made) in the presence of the Director-General or an authorized representative of the Director-General and is kept in the employee's personal file. The DirectorGeneral takes an oath before the General Assembly.

The above-mentioned Rules and Regulations also set out the procedure for accepting honors and gifts by employees. No employee shall, without the prior permission of the Director-General, have the right to receive honors, awards,

${ }^{17}$ Report of the International Civil Service Commission, A/57/30. (2002). undocs.org. Retrieved from https://undocs.org/en/A/57/30(SUPP) [in English]. 
services, gifts or awards outside the International Bureau. Permission is granted only where such honors, awards, services, gifts or awards do not contravene the employee's status as an employee of an international organization. The Director-General shall determine the guidelines for the interpretation of this provision by issuing a service instruction. In cases where the Director-General is concerned, the authorization shall be issued by the Coordination Committee. Employees may not offer or promise services, gifts, rewards, or any other personal benefits to other employees or to any third party in order to obtain, refuse to accept or delay any formal decision. Similarly, employees are not entitled to solicit or accept any services, gifts, awards or any other personal benefits from other employees or any third party in exchange for making, refusing to accept or delay any formal decision (regulation 1.8). In addition, employees must not engage in any political activity that is incompatible with their status as an international civil employee or that may affect their independence and impartiality. Membership of employees in political parties is permitted, provided that such membership does not entail actions or obligations to perform actions contrary to the provisions (regulation 1.9).

The WIPO International Bureau's Staff Regulations and Rules prohibit any form of discrimination or harassment, including sexual harassment or harassment on the basis of sex, as well as physical or verbal abuse in the workplace or in connection with the performance of official duties (rule 1.5.1) $)^{18}$.

\section{Professional and ethical standards for civil servants of regional IGOs}

The need for the staff to maintain high standards of professional conduct is also envisaged in the constituent and internal acts of the Council of Europe. Thus, in particular, the Council of Europe Staff Regulations (Part III) ${ }^{19}$ states that in the performance of their duties, staff members must sign, in the presence of the Secretary-General, a declaration stating that such a person "... solemnly declares that he/she is carrying out the duties assigned to him/her as a member of the Council of Europe, in good faith... The Council of Europe's interests will be considered solely in the performance of his/her duties and in official conduct... He/she will not seek or receive any instructions in connection with the exercise of his/her functions by any government, body, organization or persons outside the Council... refrain from doing any actions that could harm moral or material to the Council". Employees must not, without the permission of the Secretary-General, accept directly or indirectly any material or other

\footnotetext{
${ }^{18}$ WIPO International Bureau's Staff Regulations and Rules. (n.d.). www.wipo.int. Retrieved from http://www.wipo.int/export/sites/www/erecruitment/ru/pdf/staff_rules_part_a.pdf [in English].

19 Council of Europe Staff Regulations. (n.d.). publicsearch.coe.int. Retrieved from https://publicsearch.coe.int/Pages/result_details.aspx?ObjectID=090000168078183a [in English].
} 
benefits conferred on them in the performance of their duties. They must exercise high care in the facts and information which they become aware of in course of their duty or in connection with it. Without the permission of the Secretary-General, they must not transmit in any form to any third party any documents or information which have not been made public. This obligation remains in force after the employee has ceased to work.

Employees, who in the performance of their duty, have to deal with issues affecting their personal interests in such a way that this may affect their objectivity, should report this to their immediate supervisor. They should be relieved of responsibility for any matter concerning themselves or their family member (Art. 25, 33-36).

The Council of Europe has developed rules concerning the standards of conduct for members of the Parliamentary Assembly, which have been enshrined in the Code of Conduct for Members of the Parliamentary Assembly of the Council of Europe ${ }^{20}$. It sets out general principles of conduct to be followed by the Assembly members in the performance of their powers, including: honestly, integrity; impartiality. They must make decisions solely in the service of society without being bound by any instructions that would jeopardize compliance with the Code by the staff of the Assembly; use the resources available to them in a responsible manner; promote and uphold the principles set out; adhere to established rules of conduct; etc. (Art. 5).

Standards of conduct for the OSCE officials provided by the Rules of Procedure (Section II Responsibilities and Privileges) ${ }^{21}$, in addition to which the OSCE Code of Conduct for staff/mission members was adopted, which stipulates that OSCE officials should always carry out their activity at the highest personal and professional level, while performing and discharging duty, to represent the OSCE. OSCE officials should not act in such a way that it is likely to discredit the secretariat, institution or mission to which they were assigned, staff and the OSCE as a whole. They must adhere to the OSCE principles, norms and obligations and the mandate of their respective agency or mission (para. 1) 2 $^{22}$ The feature of the Code is a provision that focuses on compliance in the organization of human rights and counter trade and human beings as a material breach of these rights.

In summary, the above appointed acts of the OSCE contain a number of professional and ethical standards of OSCE officials, among them: they

\footnotetext{
${ }^{20}$ Code of conduct for members of the Parliamentary Assembly. (n.d.). website-pace.net. Retrieved from http://website-pace.net/documents/10643/375483/CodeOfConduct-EN.pdf [in English].

${ }^{21}$ OSCE Staff Regulations and Staff Rules. (n.d.). publicsearch.coe.int. Retrieved from https://publicsearch.coe.int/Pages/result_details.aspx?ObjectID=090000168078183a [in English].

22 OSCE Code of conduct for staff/mission members Appendix 1 to the OSCE Staff Regulations and Staff Rules, Permanent Council Decision 550/Corr.1. (2003). www.osce.org. Retrieved from https://www.osce.org/secretariat/31781?download=true [in English].
} 
should behave at any time so as it corresponds to the status of international civil servant; be treated equally and with respect, regardless of gender, race, creed or religion, nationality, ethnic or social background, age, sexual orientation, spouse status or other aspects of personal status; do not have a financial interest in any business if it is related to their official position in the OSCE; do not engage in any activity incompatible with the discharge of his/her duty in the OSCE (do not participate in any paid activity or employment outside the OSCE without the prior approval of the Secretary); do not use, disseminate or publish information that became known to them through their official position; compensate the damages caused to the organization; take care of organization security and more.

Ethical standards should include the following: not using the post for their own personal benefit; not accepting any reward or gift that goes beyond mere politeness. The Secretariat, its institution or mission, its staff/members must not receive any honor, award, commitment or gift in excess of 40 Euros from any government or from any source outside the OSCE without the permission of the Secretary-General and their respective head of institution/mission.

Regulations on civil servants found their consolidation in the Agreement on the Status of the North Atlantic Treaty Organization, National Representatives and International Staff of 1951, where attention is focused generally on the privileges and immunities of employees of various categories ${ }^{23}$.

In the CIS also the attention is paid to the proper level of standards of conduct for employees of the organization, the legal basis for the organization in this area is the Agreement on legal status of officials and the staff of bodies of the CIS of 2003, the Convention on the Inter-Parliamentary Assembly of the CIS of 1995. In particular, the Agreement of 2003 provides that officials and employees of the Commonwealth bodies must not engage in any activity other than scientific, creative and teaching activity (Art. 7) ${ }^{24}$. A special feature of the Commonwealth acts is also the emphasis on the privileges and immunities of the staff of the organization, subject to Art. VII of the Convention on the Privileges and Immunities of the United Nations of 1946 relating to the issuance of passes.

\section{CONCLUSIONS}

An analysis of the provisions of the constituent internal statutes of the IGO on the status of staff gave reason to determine that the distinctive features of an

23 Agreement on the status of the North Atlantic Treaty Organization, National Representatives and International Staff signed in Ottawa. (n.d.). www.nato.int. Retrieved from https://www.nato.int/cps/en/natohq/official_texts_17248.htm? [in English].

${ }^{24}$ Soglashenie o pravovom statuse lits i sotrudnikov organov Sodruzhestva Nezavisimyh Gosudarstv [Agreement on legal status of officials and the staff of bodies of the Commonwealth of Independent States]. (2003). cis.minsk.by. Retrieved from http://cis.minsk.by/reestr/ru/ index.html\#reestr/view/text?doc=1384 [in Russian]. 
international civil servant are loyalty to the organization, fulfillment of international rather than national obligations, compliance with high professional standards, which is a guarantee that the international civil service - an effective instrument to carry out its duties and aspirations of the peoples of the world.

The basic professional standards of conduct for international civil servants envisaged at the universal and regional levels include the following: independence, impartiality, high level of culture, proficiency, international loyalty, non-discrimination, non-disclosure of confidential information, which became a refusal to hold office, ban on past employment, ban on influencing the organization's interests or third party requests, etc.; priority of interests of an IGO. This prevent emergence of conflicting or competing interests that could affect their impartiality.

Ethical standards should include: not accepting honors, awards, service, and gifts outside the organization; prohibition of any form of discrimination or harassment, including sexual harassment or harassment on the basis of sex, as well as physical or verbal abuse in a workplace or in connection with the performance of official duties.

Ensuring compliance with the standards of conduct for the international civil service is aimed at achieving efficiency and maintaining the authority of the IGO. International civil servants must adhere to high values, principles and standards, as they have a primary responsibility for the implementation of the broad ideals they have committed to serve. At the same time, IGOs are obliged to enforce these standards through their regulatory framework, including rules, regulations and other internal administrative acts, and, in addition, by improving the qualification of the staff of the IGO through various forms of trainings, seminars and more.

\section{SUMMARY}

The article analyzes the legal basis (constituent and internal acts) of international intergovernmental organizations of universal and regional nature, in particular: the United Nations, the World Intellectual Property Organization, the Organization for Security and Cooperation in Europe, the Council of Europe, the North Atlantic Treaty Organization, and the Commonwealth of Independent States containing the professional and ethical standards for civil servants. Emphasis is placed on the provisions of universal international instruments, particularly, the Standards of Conduct for International Civil Service, adopted within the UN, which are a comprehensive codification of rules designed to regulate the various fields of activity of international civil servants. It is stated that the provisions laid down in the UN Standards contain general rules of professional ethics for civil servants, which are also enshrined in the acts of international regional organizations. The importance of the United Nations System Staff College 
(UNSSC), which is an independent system-wide institution dedicated to the accumulation and dissemination of knowledge and training, to promote coherent governance culture throughout the Organization is emphasized. The internal acts of the International Bureau of the World Intellectual Property Organization, which contain the relevant norms, are characterized.

Attention is paid to the acts of regional international organizations, the Council of Europe Staff Regulations, the OSCE Rules of Procedure, the OSCE Code of Conduct for staff/mission members, the Agreement on the Status of the North Atlantic Treaty Organization, National Representatives and International Staff, the Agreement on legal status of officials and the staff of bodies of the CIS, to establish the professional and ethical standards of their employees. Emphasis is also placed on special features of the provisions of regional international organizations acts regarding the standards for their employees, for instance, it is noted that the OSCE acts emphasize the observance of human rights and anti-trafficking by employees of the Organization as a material violation of these rights; ensuring the safety of the organization's activity, etc. Relevant conclusions are made.

\section{REFERENCES}

1. Franz von Liszt. (1909). Mezhdunarodnoe pravo v sistematicheskom izlozhenii [International law in systematic content]. (V.E. Grabar, Trans). Moscow: Tipografiia K. Mattissena [in Russian].

2. Report of the International Civil Service Commission for the year 2017, A/72/30. (2017). undocs.org. Retrieved from https://undocs.org/en/ A/72/30 [in English].

3. Syroid, T.L. (2017) Vnutrishnia systema vreghuliuvannia sporiv Orghanizatsiyi Obiednanykh Natsiy [Internal Dispute Settlement System of the United Nations]. V.N. Karazin Kharkiv National University Journal, 23, 165-168 [in Ukrainian].

4. Charter of the United Nations. (n.d.). www.un.org. Retrieved from https://www.un.org/en/charter-united-nations/index.html [in English].

5. Shulipa O. (2015). Standarty povedinky mizhnarodnyh tsyvilnyh sluzhbovtsiv [Standards of Conduct for the International Civil Servants]. Scientific Journal "Chronicles of KUL", 2, 368-371 [in Ukrainian].

6. Staff Rules and Staff Regulations of the United Nations, ST/SGB/2014/1. (2014). undocs.org. Retrieved from https://undocs.org/ en/ST/SGB/2014/1 [in English].

7. Standards of Conduct for the International Civil Service. (n.d.). unesdoc.unesco.org. Retrieved from https://unesdoc.unesco.org/ark:/ 48223/pf0000230879 [in English].

8. Resolution adopted by the General Assembly Statute of the United Nations System Staff College in Turin, Italy, A/RES/55/278. (n.d.). 
documents-dds-ny.un.org. Retrieved from https://documents-dds-ny.un.org/ doc/UNDOC/GEN/N00/575/77/PDF/N0057577.pdf?OpenElement [in English].

9. Secretary-General's bulletin Post-employment restrictions, ST/SGB/2006/15. (2006). undocs.org. Retrieved from https://undocs.org/en/ ST/SGB/2006/15 [in English].

10. Report of the International Civil Service Commission, A/57/30. (2002). undocs.org. Retrieved from https://undocs.org/en/A/57/30(SUPP) [in English].

11. WIPO International Bureau's Staff Regulations and Rules. (n.d.). www.wipo.int. Retrieved from http://www.wipo.int/export/sites/www/ erecruitment/ru/pdf/staff_rules_part_a.pdf [in English].

12. Council of Europe Staff Regulations. (n.d.). publicsearch.coe.int. Retrieved from https://publicsearch.coe.int/Pages/result_details.aspx? ObjectID=090000168078183a [in English].

13. Code of conduct for members of the Parliamentary Assembly. (n.d.). website-pace.net. Retrieved from http://website-pace.net/documents/ 10643/375483/CodeOfConduct-EN.pdf [in English].

14. OSCE Staff Regulations and Staff Rules. (n.d.). publicsearch.coe.int. Retrieved from https://publicsearch.coe.int/Pages/result_details.aspx? ObjectID=090000168078183a [in English].

15. OSCE Code of conduct for staff/mission members Appendix 1 to the OSCE Staff Regulations and Staff Rules, Permanent Council Decision 550/Corr.1. (2003). www.osce.org. Retrieved from https://www.osce.org/ secretariat/31781?download=true [in English].

16. Agreement on the status of the North Atlantic Treaty Organization, National Representatives and International Staff signed in Ottawa. (n.d.). www.nato.int. Retrieved from https://www.nato.int/cps/en/natohq/official_ texts_17248.htm? [in English].

17. Soglashenie o pravovom statuse lits i sotrudnikov organov Sodruzhestva Nezavisimyh Gosudarstv [Agreement on legal status of officials and the staff of bodies of the Commonwealth of Independent States]. (2003). cis.minsk.by. Retrieved from http://cis.minsk.by/reestr/ru/index.html\# reestr/view/text?doc=1384 [in Russian].

\section{Information about the author: Tetiana Syroid, D.J.S., Professor,} Head of the Department of International and European Law,

V.N. Karazin Kharkiv National University 4, Svobody Square, Kharkiv, 61022, Ukraine ORCID ID: orcid.org/0000-0002-8165-4078 